\title{
Biodegradation of Polycyclic Aromatic Hydrocarbons in Crude oil-Contaminated Soil using Composted Market Waste
}

\section{*BADA, BS; TOWOLAWI, AT; ANYIAM, DC}

\author{
Department of Environmental Management and Toxicology, Federal University of Agriculture, Abeokuta, Ogun \\ State, Nigeria.*Corresponding author Email: badabs@funnab.edu.ng, +234803-725-096; \\ taofiktowolawi@yahoo.com; anyiamdeborah@gmail.com
}

\begin{abstract}
Release of crude oil and its products into the environment has resulted in many problems that are of global concern. The objective of this study was to determine effect of Composted Market Waste (CMW) on the degradation of Polycyclic Aromatic Hydrocarbons (PAHs) in crude oil-contaminated soil. Pot experiment was carried out with $1 \mathrm{~kg}$ of soil in 7 litres perforated container contaminated with $10 \% \mathrm{w} / \mathrm{w}$ crude oil, followed by amendment with CMW at 0, 350 and $450 \mathrm{~g}$. The soil was analysed for PAH after 21 days using GC-FID. Acenaphthylene, Acenaphthene, Phenanthrene, Benzo (g,h,i) perylene, Indeno (1,2,3-cd) perylene, Pyrene and Benzo (b) fluoranthene were present in the crude oil-contaminated soil. Concentrations of PAHs at the end of the experiment were 188.40 , 38.45 and $32.73 \mathrm{ppm}$ in control, 350 and $450 \mathrm{~g}$ respectively. Composted market waste enhanced degradation of PAHs in crude oil- contaminated soil.
\end{abstract}

\section{DOI: https://dx.doi.org/10.4314/jasem.v22i1.26}

Copyright: Copyright $(92018$ Bada et al. This is an open access article distributed under the Creative Commons Attribution License (CCL), which permits unrestricted use, distribution, and reproduction in any medium, provided the original work is properly cited

Dates: Received 14 June 2017; received in revised form 09 December 2017; accepted 31 December 2017

Keywords: PAH, Degradation, Crude oil, Compost

Polycyclic Aromatic compounds (PAHs) have a strong feature of mutagenic and carcinogenic effect. Broadly, crude-oil spillage has a serious hazard to human health and the environment, the associated environmental impact includes intensification of the greenhouse effect, acid rain, water quality impairment and groundwater contamination which becomes unfit for long time use. It contributes to air pollution through gas flaring resulting in respiratory diseases (Jike, 2004). It also poses risks to human health, biological environment and vegetation. Birds and mammals are vulnerable to oil spills when their habitats become contaminated thereby reducing their reproductive rates and survival as well as triggering physiological impairment. Thus, adverse effects resulting from soil pollution increases yearly and becomes a key concern to the public (The Ministry of Environmental Protection, 2008). Available techniques to totally restore polluted soil are still growing, mostly at the stage of laboratory simulation and research with little practical engineering practice. Consequently, the lowest-cost mitigation for soil protection is to attach importance to soil protection policies with possible, easily available and cost effective techniques. One of such techniques is bioremediation. Remediation methods for any contaminated soil include chemical, physical and biological processes. The first two (physical and chemical) methods are obviously not cost-effective compared to the latter (biological treatment, bioremediation), which involves use of microorganisms to remove hydrocarbon pollutants from the environment (Collin, 2001). This method is appreciated for being efficient, cost effective and environmentally sustainable. Bioremediation researches have been carried out to restore oil and related contaminated soils using composted household waste (Adekunle, 2010) and Kenaf (Bada et al., 2014). Research had been conducted on the remediation of hydrocarbon-contaminated soil with application of biostimulation (nutrient addition) to enhance degradation (Manuela et al., 2012) with little work on composted market waste. The objective of this study was to determine effect of Composted Market Waste on the degradation of Polycyclic Aromatic Hydrocarbons (PAHs) in crude oilcontaminated soil.

\section{MATERIALS AND METHODS}

Soil sample collection, preparation and analysis: The composted market waste was purchased from Ondo State Organic Fertilizer Company. Soil sample was collected from the Teaching and Research Farm, Federal University of Agriculture Abeokuta, Ogun State. The soil was air dried, sieved and analysed for physical and chemical properties. Soil sample weighing $1 \mathrm{~kg}$ was prepared in 7 litres pot and spiked with $10 \% \mathrm{w} / \mathrm{w}$ of crude oil. This was followed by adding 0,350 and $450 \mathrm{~g}$ of composted market waste. Soil samples were collected first, fourth and seventh week after application of composted market waste. The soil parameters analysed include $\mathrm{pH}$ (Bada et al., 2014), Organic carbon by wet dichromate acid oxidation method (Nelson and Sommer, 1982), Total nitrogen was determined by Micro-Kjeldahl digestion-distillation procedure and available 
phosphorus by Olsen method (Bremner, 1982). The PAHs were analysed with GC-FID.

Description of the PAHs analysis: Sampling was performed by opening the reactor and mixing its content well to get representative grab samples: 20 $30 \mathrm{~g}$. Five gram from each sample was extracted with acetone / dichloromethane as solvent for 2 hours. After this extraction, it was left to evaporate during 24 hours; the remaining residue (extract) was then dissolved in $10 \mathrm{ml}$ dichloromethane. One micro litre extract of this solution was injected in Gas Chromatograph (Agilent GC --7890A) equipped with Flame Ionization Detector (FID) and Splitless Injector, HP5 (30 m× $320 \mathrm{um} \times 0.25 \mathrm{um})$ column was used for the identification of various Polycyclic Aromatic Hydrocarbons (PAHs). Initial temperature was maintained at $60^{\circ} \mathrm{C}$ for 1 minute, then it was increased at a rate of $12^{\circ} \mathrm{C} / \min$ until $210^{\circ} \mathrm{C}$, then another rate of $8^{\circ} \mathrm{C} / \min$ until $320^{\circ} \mathrm{C}$. The level of PAH was calaculated as expressed by equation 1 .

$$
P A H=\frac{\text { Concentration in } \frac{n g}{\mu L} \cdot l}{\text { weight of soil }(g)} \quad \ldots .1
$$

Statistical analyses: The data collected were subject to descriptive (mean and standard deviation) and inferential (ANOVA) statistics and means were separated using Duncan's Multiple Range Test

\section{RESULTS AND DISCUSSION}

Characterization of the soil before contamination with crude oil showed that the soil had sandy-loam texture and was low in phosphorus, nitrogen and potassium with alkaline $\mathrm{pH}$ (Table 1). Proximate analysis of the composted market waste was also shown in Table 1 . Other factors that governed the fate and behaviour of organic pollutant in the soil include soil characteristics and environmental factors. It was demonstrated that organic waste amendment had the potential of remediating hydrocarbons contaminated soil with significant reduction because the amendment could be more effective than other amendments in providing an alternative source of $\mathrm{N}$ and $\mathrm{P}$ to stimulate microbial activity (Agamuthu and Dadrasnia, 2013). It is obvious that environmental factors (such as soil $\mathrm{pH}$, nutrient availability and the bioavailability of the contaminant) which depend on site / medium may have influence on bioremediation process by impeding growth of the pollutantdegrading microorganisms (Osuji et al., 2007). The addition of composted market waste influenced the PAHs biodegradation rates. This might be due to the biodegradation process which reduced the introduced contaminants.

Table 1: Properties of soil and Composted Market Waste (CMW)

\begin{tabular}{llll}
\multicolumn{4}{c}{ Table 1: Properties of soil and Composted Market Waste (CMW) } \\
\hline Soil parameters & Value & CMW properties & Value \\
\hline $\mathrm{pH}$ & 7.30 & Nitrogen $(\%)$ & 1.23 \\
Sand (\%) & 740.00 & Phosphorus $(\%)$ & 0.098 \\
Clay $(\%)$ & 95.00 & Potassium $\left(\mathrm{cmol} \mathrm{kg}^{-1}\right)$ & 3.00 \\
Silt $(\%)$ & 165.00 & Calcium $(\mathrm{cmol} \mathrm{kg})$ & 3.22 \\
Texture & Sandy loam & Magnesium $\left(\mathrm{cmol} \mathrm{kg}^{-1}\right)$ & 1.20 \\
Exchange $\mathrm{K}\left(\mathrm{mg} \mathrm{kg}^{-1}\right)$ & 17.00 & $\mathrm{NA}$ & NA \\
Organic carbon $\left(\mathrm{g} \mathrm{kg}^{-1}\right)$ & 5.35 & $\mathrm{NA}$ & NA \\
Phosphorus $\left(\mathrm{mg} \mathrm{kg}^{-1}\right)$ & 0.52 & NA & NA \\
Total nitrogen $\left(\mathrm{g} \mathrm{kg}^{-1}\right)$ & 0.13 & $\mathrm{NA}$ & NA \\
\hline \multicolumn{4}{c}{ Values are mean \pm standard deviation. NA = Not Available }
\end{tabular}

Values are mean \pm standard deviation. NA $=$ Not Available

Effect of compost application on soil properties: Effect of compost application on soil $\mathrm{pH}$, Electrical Conductivity (EC) and Potassium (K) were shown in Table 2 while the effects on soil phosphorus, total nitrogen and organic carbon were shown in Table 3. Soil $\mathrm{pH}$ is a major factor influencing the availability of elements in the soil for plant uptake (Marschner, 1995). The $\mathrm{pH}$ of the contaminated soil varied significantly $(\mathrm{p}<0.05)$ except in the non-amended soil from week 1 to week 7 in all the treatments (Table 2). The compost increase the soil $\mathrm{pH}$ value (tend alkaline) which is most ideal for most crude oil utilizing bacteria and this indicated that strong acidity is a limitation in biodegradation. There was a view that low $\mathrm{pH}$ affected the rate of oil degradation by bacteria in oil contaminated soil (Okoh, 2006). Acidic soil is a problem for agricultural soil because more metal cations including $\mathrm{Cd}, \mathrm{Cu}, \mathrm{Hg}, \mathrm{Ni}, \mathrm{Pb}$ and $\mathrm{Zn}$ are available in the soil at very low pH (Bada et al., 2014). However, such acidic soil does not favour microbial degradation. It was observed in this study that alkaline soil influenced by the compost favoured microbial degradation. Phenanthrene degradation was observed (Wong et al., 2002) with liquid media of $\mathrm{pH}$ values ( $\mathrm{pH}$ 5.5-7.5) and an organism isolated from a petroleum-contaminated soil, The effects of composted market waste on soil electrical conductivity, potassium and phosphorus varied significantly $(\mathrm{p}<0.05)$ from week 1 to week 7 (Tables 2 and 3 ). The amended soil electrical conductivity significantly $(\mathrm{p}<0.05)$ reduced from week 1 to week 7 at $350 \mathrm{~g} \mathrm{CMW}$, increased in 0 CMW and varied in $450 \mathrm{~g}$ CMW (Table 2). The amended soil potassium significantly $(\mathrm{p}<0.05)$ reduced from week 1 to week 7 in $350 \mathrm{~g}$ but varied in 0 and $450 \mathrm{~g}$ treatments (Table 2). The amended soil phosphorus significantly $(\mathrm{p}<0.05)$ increased in the 0 , varied in $350 \mathrm{~g}$ but reduced in $450 \mathrm{~g}$ from week 1 to week 7 (Table 3). This corroborated the observation of Atlas and Bartha (1977) who reported that the effectiveness of compost amended treatments could vary and be related to the heterogeneity of soils and 
crude oil samples as well as possible interactions

constituents.

between the soil amendments and the natural soil

Table 2: Effect of compost application on the contaminated soil pH, Electrical Conductivity (EC) and Potassium (K)

\begin{tabular}{|c|c|c|c|c|c|c|c|c|c|}
\hline \multirow{2}{*}{$\begin{array}{l}\text { Compost } \\
(\mathrm{g})\end{array}$} & \multicolumn{3}{|c|}{$\mathrm{pH}$} & \multicolumn{3}{|c|}{$\operatorname{EC}\left(\mu \mathrm{S}^{-1}\right)$} & \multicolumn{3}{|c|}{$\mathrm{K}\left(\mathrm{cmol} \mathrm{kg}^{-1}\right)$} \\
\hline & 2 & 4 & 6 & 2 & 4 & 6 & 2 & 4 & 6 \\
\hline & & & & & WAA & & & & \\
\hline 0 & $7.39 \pm 0.0^{\mathrm{a}}$ & $7.73 \pm 0.0^{\mathrm{a}}$ & $7.79 \pm 0.0^{\mathrm{a}}$ & $1515 \pm 2.0^{\mathrm{a}}$ & $2141.00 \pm 1.0^{\mathrm{abb}}$ & $2250 \pm 2.0^{\mathrm{a}}$ & $40.00 \pm 2.3^{\mathrm{c}}$ & $110.00 \pm 10.0^{\mathrm{a}}$ & $40.00 \pm 2.0^{c}$ \\
\hline 350 & $7.39 \pm 0.1^{\mathrm{a}}$ & $7.51 \pm 0.1^{\mathrm{bc}}$ & $7.44 \pm 0.1^{\mathrm{d}}$ & $1844 \pm 31.5^{\mathrm{a}}$ & $1776 \pm 142.5^{\mathrm{c}}$ & $1332 \pm 99.5^{\mathrm{c}}$ & $125.00 \pm 5.0^{\mathrm{a}}$ & $100.00 \pm 10.0^{\mathrm{a}}$ & $70.00 \pm 20.0^{\mathrm{bc}}$ \\
\hline 450 & $7.92 \pm 0.1^{\mathrm{a}}$ & $7.45 \pm 0.0^{\mathrm{c}}$ & $7.75 \pm 0.1^{\mathrm{ab}}$ & $1785 \pm 657.0^{\mathrm{a}}$ & $1841 \pm 86.0^{\mathrm{bc}}$ & $1570 \pm 168.5^{\mathrm{bc}}$ & $105.00 \pm 55.0^{\mathrm{abc}}$ & $95.00 \pm 25.00^{\mathrm{a}}$ & $130.00 \pm 0^{\mathrm{a}}$ \\
\hline 550 & $8.09 \pm 0.1^{\mathrm{a}}$ & $7.83 \pm 0.2^{\mathrm{a}}$ & $7.68 \pm 0.1^{\mathrm{bc}}$ & $2047 \pm 665.0^{\mathrm{a}}$ & $1628 \pm 258.5^{\mathrm{c}}$ & $1729 \pm 15.5^{\mathrm{b}}$ & $120.00 \pm 5.00^{\mathrm{a}}$ & $100.00 \pm 50.00^{\mathrm{a}}$ & $80.00 \pm 30.00^{\mathrm{b}}$ \\
\hline 650 & $8.00 \pm 0.1^{\mathrm{a}}$ & $7.68 \pm 0.2^{\mathrm{abc}}$ & $7.59 \pm 0.1^{\mathrm{c}}$ & $1888 \pm 754.0^{\mathrm{a}}$ & $2215 \pm 262.3^{\mathrm{a}}$ & $1474 \pm 257.0^{\mathrm{bc}}$ & $50.00 \pm 10.00^{\mathrm{bc}}$ & $45.00 \pm 5.00^{\mathrm{b}}$ & $120.00 \pm 20.00^{\mathrm{a}}$ \\
\hline
\end{tabular}

Values are mean \pm standard deviation. Different superscript across the row indicates significant $(\mathrm{p}<0.05)$ difference. WACA $=$ Weeks After Compost Application.

Table 3: Effect of compost application on the contaminated soil Phosphorus (P), Total Nitrogen and Organic Carbon (OC)

\begin{tabular}{|c|c|c|c|c|c|c|c|c|c|}
\hline \multirow[t]{2}{*}{ Compost (g) } & \multicolumn{3}{|c|}{$\mathrm{P}\left(\mathrm{mg} \mathrm{kg}^{-1}\right)$} & \multicolumn{3}{|c|}{$\mathrm{TN}\left(\mathrm{g} \mathrm{kg}^{-1}\right)$} & \multicolumn{3}{|c|}{$\mathrm{OC}\left(\mathrm{g} \mathrm{kg}^{-1}\right)$} \\
\hline & 2 & 4 & 6 & 2 & 4 & 6 & 2 & 4 & 6 \\
\hline & & & & & WACA & & & & \\
\hline 0 & $128.0 \pm 1.0^{\mathrm{c}}$ & $214.3 \pm 4.5^{\mathrm{a}}$ & $250.0 \pm 2.0^{\mathrm{a}}$ & $0.16 \pm 0.01^{b}$ & $0.37 \pm 0.01^{\mathrm{a}}$ & $0.36 \pm 0.06^{\mathrm{ab}}$ & $1.65 \pm 0.01^{\mathrm{d}}$ & $3.98 \pm 0.01^{\mathrm{a}}$ & $3.87 \pm 0.02^{\mathrm{abc}}$ \\
\hline 350 & $192.7 \pm 47.5^{\mathrm{b}}$ & $339.9 \pm 113.3^{\mathrm{a}}$ & $200.0 \pm 30.0^{\mathrm{a}}$ & $0.53 \pm 0.03^{\mathrm{a}}$ & $0.36 \pm 0.01^{\mathrm{a}}$ & $0.34 \pm 0.02^{\mathrm{b}}$ & $5.57 \pm 0.34^{\mathrm{a}}$ & $3.92 \pm 0.01^{\mathrm{ab}}$ & $3.79 \pm 0.04^{\mathrm{c}}$ \\
\hline 450 & $330.0 \pm 5.0^{\mathrm{a}}$ & $273.4 \pm 101.6^{\mathrm{a}}$ & $240.0 \pm 35.0^{\mathrm{a}}$ & $0.58 \pm 0.04^{\mathrm{a}}$ & $0.37 \pm 0.01^{\mathrm{a}}$ & $0.37 \pm 0.01^{\mathrm{a}}$ & $6.15 \pm 0.44^{\mathrm{a}}$ & $3.83 \pm 0.40^{\mathrm{b}}$ & $3.80 \pm 0.50^{\mathrm{bc}}$ \\
\hline 550 & $282.7 \pm 22.5^{\mathrm{a}}$ & $230.5 \pm 27.4^{\mathrm{a}}$ & $213.2 \pm 91.9^{\mathrm{a}}$ & $0.56 \pm 0.01^{\mathrm{a}}$ & $0.37 \pm 0.01^{\mathrm{a}}$ & $0.37 \pm 0.01^{\mathrm{a}}$ & $5.19 \pm 0.12^{\mathrm{a}}$ & $3.87 \pm 0.80^{\mathrm{b}}$ & $3.89 \pm 0.60^{\mathrm{a}}$ \\
\hline 650 & $315.0 \pm 20.0^{\mathrm{a}}$ & $218.8 \pm 7.9^{\mathrm{a}}$ & $268.1 \pm 6.9^{\mathrm{a}}$ & $0.54 \pm 0.03^{\mathrm{a}}$ & $0.37 \pm 0.01^{\mathrm{a}}$ & $0.37 \pm 0.02^{\mathrm{a}}$ & $5.99 \pm 0.30^{\mathrm{a}}$ & $3.86 \pm 0.01^{\mathrm{b}}$ & $3.88 \pm 0.03^{\mathrm{ab}}$ \\
\hline
\end{tabular}

Values are mean \pm standard deviation. Different superscript across the row indicates significant $(\mathrm{p}<0.05)$ difference. WACA $=$ Weeks after Compost Application.

This observation indicated that the effectiveness of each treatment in any soil need be evaluated on a case specific basis. The total nitrogen significantly $(\mathrm{p}<$ 0.05 ) decreased in amended contaminated soil from week 1 to week 7 (Tables 3). The decrease in the total nitrogen content was in accordance with Chang et al. (2008) who attributed it to mineralization activities in the soil amended with the market waste compost. The observed decrease in total nitrogen might be due to the high demand of microorganisms for nucleic acid synthesis and other cellular processes from the environment created by the oil contamination. Microorganisms generally require mineral (inorganic) nutrients sources for growth. Organic carbon decreased significantly $(\mathrm{p}<0.05)$ from week 1 to week 7 in the contaminated soil (Table 3 ). This might be as a result of microorganisms in the composted market waste utilizing the organic carbon for their cell carbon (Eneje et al., 2012). .

Effect of compost application on the soil Polycyclic Aromatic Hydrocarbon content: The potential transformation of Polycyclic Aromatic Hydrocarbon (PAHs) which are complex aromatic molecules has been tried with the ability of a variety of microbes (fungi and bacteria) through laboratory-based work due to their persistence and toxicity problems in the environment and mmicrobial activity is driven by pollutant concentration (Bartha, 1986). The first stage of degradation process (decomposition stage) is normally characterized by an intense microbial activity and simultaneously resulting in the degradation of PAHs. The entire degradation processes and concentrations of the PAHs namely Acenaphthylene, Acenaphthene, Phenanthrene, Benzo (g,h,i) perylene, Indeno (1,2,3-cd) perylene, Fluoranthene, Pyrene and Benzo (b) fluoranthene were observed within 42 days (Figures 1 to 7). The PAHs were not detected in soil amended with 550 and $650 \mathrm{~g}$ of compost. The control (non-amended soil) had the highest PAHs concentration of 188.40 ppm when compared with the amended soil at $350 \mathrm{~g}$ : $38.45 \mathrm{ppm}$ and $450 \mathrm{~g}$ : $32.73 \mathrm{ppm}$ (Table 4). This implied that increase in the quantity of composted market waste applied resulted in the reduction of PAHs concentration and this corroborated the findings of Agamuthu and Dadrasnia (2013) where there was a rapid decrease in TPH of all soils amended with organic wastes when compared with non-amended soil. Nitrogen amendment enhance microbial degradation of PAHs (Senesi et al., 2007).

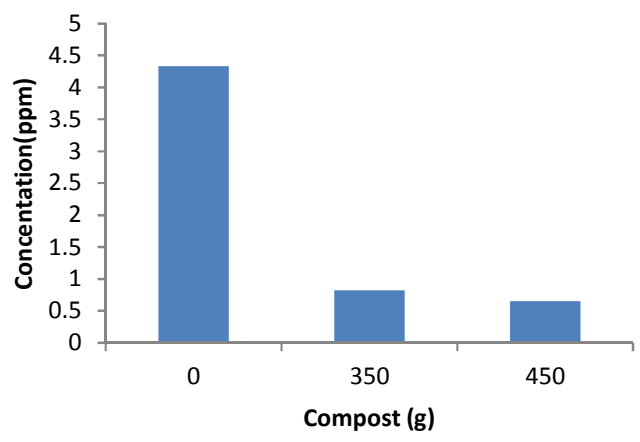

Fig 1: Concentration of Acenaphthylene in crude oil contaminated soil. 


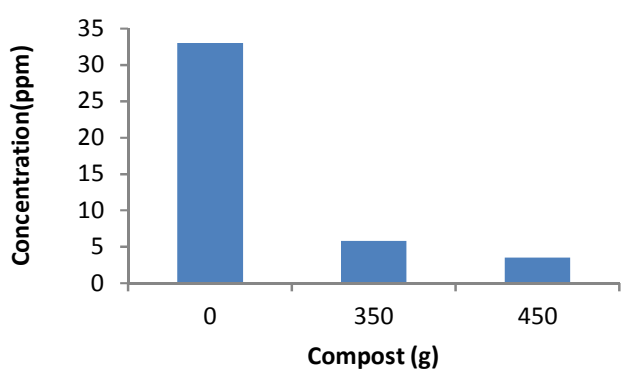

Fig 2: Concentration of Acenaphthene in crude oil contaminated soil

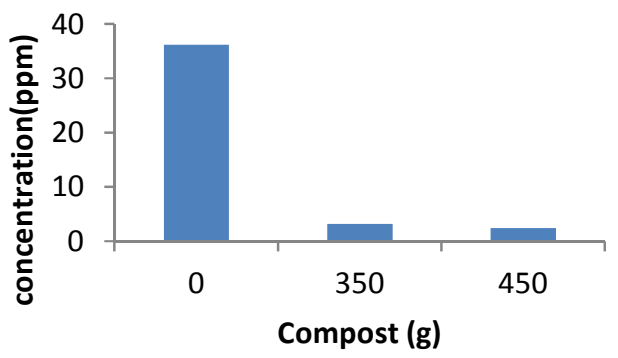

Fig 3: Concentration of phenanthrene in crude oil contaminated soil

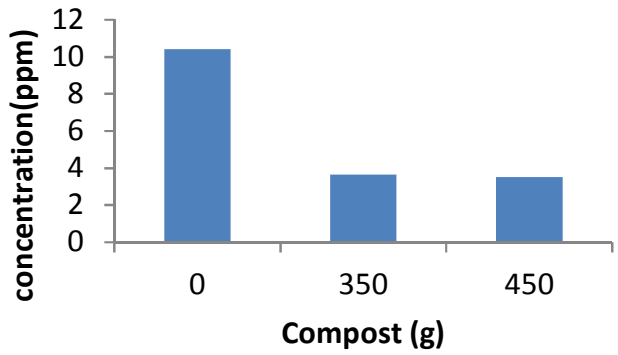

Fig 4: Concentration of Benzo (g,h,I)perylene in crude oil contaminated soil

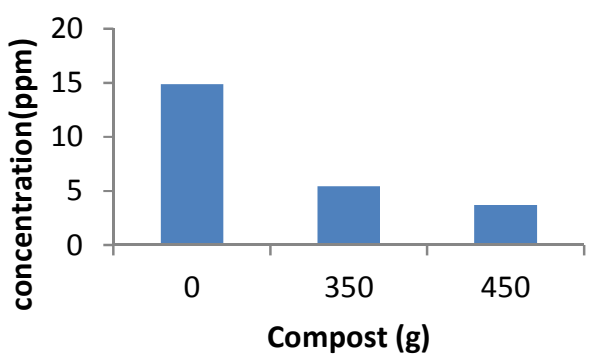

Fig 5: Concentration of Indeno (1,2,3-cd) perylene in crude oil contaminated soil

Table 4: Effect of compost application on the Total Petroleum

\begin{tabular}{ll}
\multicolumn{2}{c}{ Hydrocarbon $(\mathrm{TPH})$ content } \\
\hline Compost $(\mathrm{g})$ & TPH $(\mathrm{ppm})$ \\
\hline 0 & $188.40 \pm 17.51^{\mathrm{a}}$ \\
350 & $38.45 \pm 4.36^{\mathrm{b}}$ \\
450 & $32.73 \pm 3.64^{\mathrm{b}}$ \\
\hline \multicolumn{2}{l}{ alues are in Mean \pm Standard deviation }
\end{tabular}

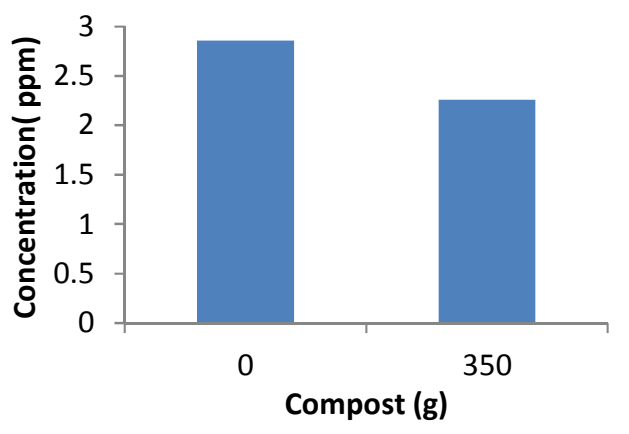

Fig 6: Concentration of Pyrene in crude oil contaminated soil

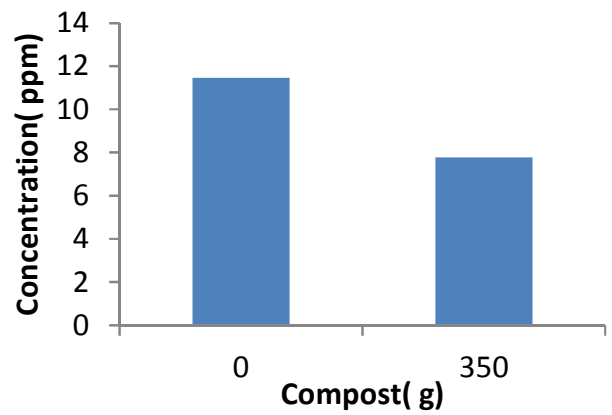

Fig 7: Concentration of Benzo (b) fluoranthene in crude oil contaminated soil

Conclusion: Composted market waste improved soil fertility and enhanced biodegradation of PAHs in crude oil-contaminated soil.

\section{REFERENCES}

Agamuthu, P.; Dadrasnia, A. (2013). Potential of biowastes to remediate diesel fuel contaminated soil.Global NEST Journal, 15(4): 474 - 484.

Adekunle, I M (2010). Evaluating environmental impact of Nigerian composted wastes using laboratory extraction test. Environ. Eng. Manage.Journal, 9: 721-729.

Atlas, RM; Bartha, R (1977). Stimulated petroleum biodegradation. Crit. Rev. Microbiol. 5: 371 386.

Bada, BS; Arowolo, TA; Ozoike, PN (2014). Assessment of heavy metal content of soil and Kenaf (Hibiscus cannabinus l.) in a nutrient degraded soil amended with dairy sludge. Journal of Applied Phytotechnology in Environmental Sanitation, 3(4): 137 - 145.

Bartha, R (1986). Microbial ecology: fundamentals and applications. Addisson_Wesley Publ., Reading, Mass.

Bremner, JM (1982). Inorganic nitrogen. In Page A. L, Miller, R. H and Keeney, D. R. (Edition): Methods of soil analysis Part II 2nd Edition. 
American society of agronomy, Madison Wiscousin. In: Anderson J. M. and Ingram, J. S. (Eds) Tropical soil biology and fertility. A handbook of methods. Inf. Press Eyasham. Pp $10-85$.

Chang, EH; Chang, RS; Wang, FN (2008). Effect of different types of organic fertilizers on the chemical properties and enzymatic activities of an oxisol under intensive cultivation of vegetables for 4 years. Soil Sci.Plant Nutr. 54: 587 - 599.

Collin, PH (2001). Dictionary of ecology and the environment, fourth ed. Peter Collin Publishing, London.

Eneje, RC; Nwagbara, C.; Uwumarongie-Ilori, EG (2012). Amelioration of chemical properties of crude oil contaminated soil using compost from Calapoigonium mucunoides and poultry manure. International Research Journal of Agricultural Science and Soil Science, 2(6): 246 -251 .

Jike, VT (2004). Environmental degradation, social disequilibrium and the dilemma of sustainable development in the Niger-Delta of Nigeria. Journal of Black Studies, 34(5): 686 - 701.

Manuela, T.; Vesna, M.; Francesca, C.; Cristiano, CB; Maurizio, C (2012). Effects of biostimulation and bioaugmentation on diesel removal and bacterial community. International Biodeterioration \& Biodegradation, 66: 39-46.
Marschner, H (1995). Mineral nutrition of higher plants (2nd ed.). New York, Academic Press, 56(4): 889.

Nelson; Sommer, LE (1982). Total carbon, organic carbon, organic matter. In Page AL.; Miller, RH. and Keeney, DR., (Edition). Method of soil analysis Part 2. Agronomy Monography, Second Edition. Pp 539 - 579.

Okoh, IO (2006). Biodegradation alternative in the clean-up of petroleum hydrocarbon pollutants. Biotechnology and Molecular Biology Review, 1(2): 38 - 50 .

Osuji, LC; Nwoye, I (2007). An appraisal of the impact of petroleum hydrocarbons on soil fertility: The Owaza Experience, African Journal of Agric. Resources, 2 (B): 318 - 324.

Senesi, N.; Plaza, C.; Brunetti, G.; Polo, A (2007). A comparative survey of recent results on humiclike fractions in organic amendments and effects on native soil humic substances. Soil Biol. Biochem., 39: 1244 - 1262.

The Ministry of Environmental Protection, 2008. Opinions on strengthening soil pollution prevention andcontrol. Document No. 48.

Wong, JWC; Lai, KM; Wan, CK; Ma, KK; Fang, M 2002). Isolation and optimisation of PAHdegradative bacteria from contaminated soil for PAH bioremediation. Wat. Air Soil Pollute. 139: $1-13$. 